\title{
Impact of Microcredit on Women Empowerment: A Case Study in the Context of Chattogram District, Bangladesh
}

\author{
Shakina Sultana Pomi* \\ Faculty of Business Administration, Southern University Bangladesh, Chattogram, Bangladesh. \\ *Correspondence: pomi@ southern.edu.bd (Shakina Sultana Pomi, Assistant Professor, Faculty of Business Administration, \\ Southern University Bangladesh, Chattogram, Bangladesh).
}

\begin{abstract}
The microcredit sector in Bangladesh has flourished over the past few years by providing financial services to poor women who were previously unreachable, and it has been successful in meeting their fundamental needs, empowering them. This paper is an attempt to find out the role of microcredit on the empowerment of women borrowers in the context of some regions of the Chattogram district. These three Upazillas were surveyed cross-sectionally. A well-structured questionnaire was used to collect data during face-to-face interviews with 50 microcredit women borrowers and 50 non-borrowers from two major microcredit providers in Bangladesh. Participants were randomly selected. Data were summarized in tabular form. As a result of the chi-square test and ANOVA, significant results were observed. The paper analyzes the role of microcredit in women's empowerment from three perspectives: psychological, social, and economic. As a result of the study, BRAC and ASA microcredit have a significant role in reducing the vulnerability of poor women in the study region by generating income, improving the living standards of borrowers, and enabling these women to become more empowered by: (a) psychological empowerment by acquiring decision-making power in household activities, (b) economic empowerment by making a contribution to living standard \& control over assets, (c) social empowerment by getting freedom of voice and mobility.
\end{abstract}

Keywords: Microcredit, Women empowerment, Impact, Borrowers, and Non-borrowers in Bangladesh.

\section{INTRODUCTION:}

The subject matter of "Women Empowerment" has become a red-hot issue all over the world, now a day. "Women empowerment" and "women equality with men" is a sizzling topic in the developing countries. Women population constitutes around $50 \%$ of the world's population. "We cannot all succeed if half of this is held back." - Malala Yousafzai. Many women around the world are unemployed. The world economy suffers a lot because of the unequal opportunity for women at workplaces. Women Empowerment reduces poverty. Sometimes, the money earned by the male member of the family is not sufficient to meet the demands of the family. The added earnings of women help the family to come out of poverty trap and in improving the living standard. Women's access to UniversePG I www.universepg.com credit positioned vivacious issue on the international agenda of 'The Fourth World Conference on Women' held in Beijing in 1995. One of the major goals of the International Year of Microcredit (2005) was topromote the role of microcredit in achieving the Millennium Development Goals. The General Assembly adopted a resolution (A/60/210), recognizing the importance of microcredit/microcredit in achieving the MDGs, especially goal \#1 (reducing poverty) and goal \#3 (gender equality and women's empowerment).

The Global Microcredit Summit-2006 has also adopted a specific target to boost half a billion people out of extreme poverty. Bangladesh is one of the density populated countries in the world. It has 160 million people in its domestic territory. 
The Human development Index (HDI) ranked Bangladesh at 138 among 189 countries in 2016 (United Nations Development Program [UNDP], 2018). Data has been revealed that 49.6 percent population live below income at US\$1.25 (UNDP, 2012). Though most of the populations live below poverty line, they need to get support to do away with their poverty. A Lot of MFIs in Bangladesh namely GB, BRAC, ASA undertook many programs to reduce poverty and to develop socio economic status of the rural poor women and have developed a success model of microcredit for the poor women (Basak, 2021). Numerous literatures and documentations in the sector of microcredit has been demonstrated the truth of positive impact of micro-credit on the empowerment of poor women by alleviating poverty and uplifting their living standard. Thus, microcredit is providing a conduit to the empowerment of rural poor women. To justify the impact of microcredit on the empowerment of poor women this study has been conducted simply on the credit recipients of two MFI's namely BRAC and ASA. BRAC and ASA are playing worth mentioning role to reduce the vulnerabilities of the poor women in the rural areas of Bangladesh. Now, BRAC and ASA have been providing microcredit and related services to 5.3 million and 5.8 million poor household respectively all over the country (Bangladesh Rural Advancement Committee [BRAC], 2019 \& Association for Social Advancement [ASA], 2019). Due to enormous penetration of BRAC and ASA into the large community of rural areas, this study chooses these two organizations to analyze the impact of microcredit on the empowerment of poor women of Hathazari, Mirsharai and Sitakunda Upazilla (sub-unit of district) of Chattogram district of Bangladesh. In the field of socio-economic development, the word 'microcredit' and 'women empowerment' got immense popularity as a research topic in the context of Bangladesh. Microcredit has contributed at least 9-12 percent to the GDP of Bangladesh (Raihan et al., 2015).

In recent years microcredit has expanded both horizontally and vertically. Success stories of Bangladesh in the field of microcredit and women empowerment draw the attention of thousands of researchers, academics, research fellow, and Non-Govt. Organizations (NGOs) activists for its unique role in empowerment of women by reducing their poverty. This study is also an attempt to share the findings in the basket of its success stories. Present study was UniversePG I www.universepg.com conducted on the role of microcrediton women empowerment steamed from the data collected from women borrowers of BRAC and ASA- the leading NGOs in this sector. Many studies have been conducted on the poverty alleviation role of microcredit in several distinct areas, but study on the said areas was few.

Most of the researches are found to focus on the variables on an aggregate basis, like monthly income, monthly expenditure, etc. A notable lack of research has been conducted on the expenditure variables separated by nutrition expenditure, education expenditure, health expenditure, and clothing expenditure. In the present study, microcredit impact was demonstrated separately for each of these variables, since all variables were taken into account to estimate the actual improvement in the condition of the poor community in the study areas. Microcredit was examined using one-way Analysis of Variance (ANOVA) and Chi-square tests to analyze whether it was associated with and contributed to income, expenditure, housing conditions, land holdings, assets, education, health and nutrition, and pure drinking water and sanitation. The aim of the present study is to examine the impact of microcredit in the Chattogram District of Bangladesh on women's empowerment and to provide policy recommendations based on the findings.

\section{Review of Literature:}

Studies evaluating the impact of microfinance on the various dimensions of empowerment of poor women borrowers have accumulated an immense body of empirical literature. It is well known that microcredit plays an important role in women's empowerment. Microcredit has been shown to have a positive effect on empowering women and improving their livelyhoods through a number of studies. Hashemi et al. (1996) studied the impact of microcredit and microfinance programmer on the lives of women and found microcredit as a significant factor contributing to empower women. Rathiranee and Semasinghe, (2015) argued that microcredit is a base to women empowerment by improving economic activities and selfemployment, assisting women meet their practical needs and increase their efficacy in their traditional roles and to gain respect and achieve more in their socially defined roles, which in turn may lead to increased esteem and self-confidence which may contribute decisively to a woman's ability and willingness to confront the social injustices and discri- 
minatory systems that they face and implies that as women become financially better-off their selfconfidence and bargaining power within the house-hold improved and this straight leads to their empowerment even during COVID-19 (Ayittey et al., 2020). Microcredit found leading to increased women empowerment through increased power in decision making. Browning and Chiappori, (1998) showed in their collective decision-making model that if behavior in the household was pare to efficient, the household's objective function takes the form of a weighted sum of individual utilities. It was assumed that by increasing the relative value of the female members' time and income, the weight and therefore the bargaining power of the female could be increased within the household (Chowdhury and Dhar, 2012; Dhar et al., 2014) which also maintain the process of shariah (Hasaan et al., 2019; Masruki et al., 2020).

Hulme and Mosley (1996) wrote a positive impact was found on borrowers; both male and female, income with an average increase over the control group ranging from 10 to 12 percent in Indonesia, to around 30 percent in Bangladesh. Hashemi et al. (1996) conducted one of the earliest studies on micro-credit and its effect on women empowerment in 1996 by a longitudinal study, conducted on 1300 married women in Bangladesh between 1991 and 1994 by comparing participants of two different microcredit programs, Grameen Bank and BRAC, with a control group divided into - a group of women with access to the same banks and another group with no access to microcredit. Hashemi et al. (1996) had assessed the empowerment via a number of factors such as women's mobility, ability to make purchase, ownership of assets, and political awareness. The survey finds a positive relationship between access to microcredit and women empowerment and Swain, (2007) examined the impact of Self-Help Groups (SHGs), a group lending form of microcredit in five Indian states. Goetz and Gupta, (1996) studied the effect of microcredit on women empowerment by conducting a questionnaire with 253 female members from Grameen Bank and BRAC, showed that married women compared to unmarried women had exercised less control over their loans and its utilization. In a study by Islam, Hossain and Afrin, (2014), 100 microcredit recipients of Grameen Bank, BRAC, and ASA were studied to determine the effect of microcredit on poverty reduction. According to an analysis of a structured questionnaire, these MFIs play an UniversePG I www.universepg.com important role in reducing poverty by creating employment and increasing the living standards of women borrowers through better education and health facilities, and thus providing them with a sense of empowerment. The income level of the Rural Microcredit (RMC) house-holds improved slightly in another study conducted by Khanom, (2014). Khandker et al. (2015) recognized interesting results on the longer-term effects of microcredit on household welfare, utilizing a panel data of households covering 87 villages of rural Bangladesh and they estimated the long run effects of microcredit on household per capita income, expenditures, poverty, non-land assets, household net-worth, male $\&$ female labor supply and schooling of children. A survey conducted by Terano, Mohamed and Jusri, (2015) on 100 credit recipients illustrated the impact of microcredit on total income level raised by using descriptive analysis, factor analysis and multiple regression analysis. Pomi, (2019) discovered that in Chattogram microcredit disbursed through BRAC and ASA play an important role in reducing poverty by enhancing the income-generating activities of borrowers and enhancing the living standards of poor women. There is a need for psychological adjustment when the women's health index is being developed (Sarkar et al., 2018). In Pomi, (2019) study, it was also noted that microcredit benefits poor women borrowers who attended BRAC and ASA for at least five years, compared to non-borrowers. For developing the positive impact related vocational education and leadership are required (Dhar, 2020; Dhar et al., 2020; Dhar and Mutalib, 2020). A study by Karim, Tania and Frarazi, (2013) found that microcredit programmes are generating positive results for many poor individuals. In a study conducted by Islam, Kabir, and Dey, (2012) on ASA and PROSHIKA, the authors argue that microcredit contributes to poverty eradication by increasing income-generating activities among poor people, and empowering them to access health, education, and reduced vulnerability. The study by Khan and Rahman, (2007) also discussed that microcredit is one of the most effective methods of eradicating poverty. In addition to Awan and Juiya, (2015), Idris, (2015), and Alnaa and Ahiakpor, (2015), microcredit was also found to have a positive impact on poverty reduction. The outcomes of giving credit to women have seen controversial issues, some researchers argue that microcredit has positive outcomes on women's empowerment while others argue that microcredit credit bring 
negative outcomes for women. Kabeer, (1999) distinguished that women's empowerment is the process to empower those who have been denied the ability to make the strategic life choices, which incorporates interrelated dimensions- resources and achievements. Kabeer, (2001) in another study has examined the relationship between micro-credit and women empowerment by interviewing both female and male microcredit program participants in two provinces in Bangladesh. The conclusion from her study was that women who received micro-credit had a higher selfworth and better access to capital. Even if participating in a microcredit program in some cases led to a higher workload, the women think positively about their increased contribution to the household income. Furthermore, she finds that in many cases microcredit increased women's decision-making ability within the household. Recently, some studies argued on the impact of microcredit with a question that the impact of microcredit is conflicting between positive, no impact and limited impact to the less poor and even negligible or negative impact on the poorest. Banerjee et al. (2015) surveyed on 52 respondents to determine the impact of microcredit and used two goods to describe the impact of microcredit on consumption expenditure. Banerjee et al. (2015) found that expenditure of "durable goods" increased but expenditure of "temptation goods" declined and no significant difference was reported on health, education or women's empowerment. In contrast, some studies have found that microcredit has neither a positive nor a negative impact on women's empowerment. A study conducted by Leach and Sitaram, (2002) discovered that microcredit has been successful in empowering women socially where economic empowerment was inaccessible due to a lack of awareness and understanding among women about business. A study by Berglund, (2007) found that empowering individuals did not have an impact on groups. Schechter (2007) observed that credit facilities helped women to run a business and earn small profits, but they were still found dependent on family members. For developing human capital (Absar et al., 2021; Dhar et al., 2017; Dhar et al., 2018; Dhar et al., 2019) and sustainable economic growth (Pomi et al., 2021) and social responsibility (Dhar et al., 2021) with proper marketing policies (Crowley et al., 2020; Sayeed et al., 2018) even during and after the pandemic, COVID-19 (Chowdhury et al., 2021; Dhar et al., 2020), microcredit plays a significant role. Although having some disagreement, the vast literature works revealed enough empirical and quasi-empirical evidence that supported the positive impact of microcredit on women empowerment. Hence without any question, it can be alleged that a well-designed microcredit or microcredit program can thus substantially change the lives of the poor women at the individual, household, enterprise and community levels and help raise the poor's out of poverty. Rahman et al. (2009) examined the impact of microcredit on women's empowerment of borrowers having different levels of income by using control-group, which showed that non-borrowers were equally empowered as microcredit borrowers.

\section{METHODOLOGY:}

This study was basically explorative in nature. The study has adopted 'purposive sampling in selecting the samples and used both unstructured and structured instruments for collection of data. Both statistical and econometric techniques and some relevant parametric tests were used for analyzing data and for conducting test hypothesis respectively.

\section{Sampling Design of the Study}

Two samples have been considered in this study. One has been selected from loan recipients (women borrowers) and the other from non-recipients of loan (non-borrowers). For simplicity, the study regarded two MFI's namely BRAC and ASA for collecting data. Data was collected from the respondents using a face-to-face interview schedule (Questionnaire). Questionnaire comprised of information related to the back-ground of respondents such as gender, age, education, number of family members and living standards, quantitative data about income generating activities of the women borrowers to improve their living standard and qualitative data that leading to the passageway of empowerment of women borrowers in terms of (a) psychological empowerment, (b) economic empowerment and (c) social empowerment.

Some structured questions and some dichotomous questions were asked to collect the information from the respondents. Structured questionnaire was used to collect data for different outcome variables indicating 'before' and 'after' of receiving credit by the borrowers and 'before 5 years back' and 'current year' for the non-borrowers respectively. Dichotomous questions had only two response alternatives - yes or no. 


\section{Selection of the Study Areas and Period of Data Collection}

This study has selected only three upazillas in Chattogram district (namely Hathazari, Sitakunda and Mirsharaiupazilla) for the purposes data collection. It was presumed that the study areas would represent the whole scenario of rural part of Bangladesh. The selection of the study areas was based on the following criteria- (a) that covered by microcredit operation of BRAC and ASA and continuing poverty reduction program since last 20 years, (b) where number of unprivileged poor women was high and (c) areas that are geographically and environmentally convenient for collection of data. The study was conducted from January, 2018 to February, 2019.

\section{Selection of the Sample of Borrowers}

Out of a total number of 25 branches, 10 branches of BRAC \& ASA ( 5 branches from BRAC and 5 from ASA) were selected to determine the credit recipients from the study areas. From each branch, one village centers and 10 groups (each groups contains at least 10 persons) have been selected for data collection. This study has selected 205 borrowers randomly at 5 percent level of significance based on standardized random sampling formula. Primarily, this study atempted to conduct interview of 205 borrowers and finally the study was successful in conducting interview of 100 borrowers and the success rate is 48.78 percent.

\section{Selections of the Sample of Non-borrowers}

Besides 100 borrowers, another set of 50 non borrower respondents were also selected as the control group who did not take any credit from BRAC or ASA or any other MFI to compare the consequences of empowerment of the study. 50 non borrower respondents were also selected randomly.

\section{Types and Sources of Data}

The Current study was based on the extensive use of primary data. Primary data were collected from the household of three Upazilla of Chattogram district namely Hathazari, Mirsharai and Sitakunda for the purpose of the study. The primary data have been collected through structured questionnaire from the 150 respondents that included both borrowers (100 respondents) of BRAC \& ASA and non-borrowers (50 respondents). Personal interview method was used to collect the data. Moreover various books, journals, website and other publications of BRAC and ASA were used for reviewing the fact thoroughly.

\section{Operational Variables}

The operational variables used in the study clearly reflected the extent of empowerment of women of both sample groups. BRAC and ASA play a dynamic role to reduce vulnerability of the poor women in the study area by income generating activities of the women borrowers and in improving their living standard leading to the passageway of empowerment of women borrowers in terms of the operational variables categorized under (a) psychological empowerment by acquiring decision-making power in the household activities, (b) economic empowerment by making contribution to living standard \& control over assets, (c) social empowerment by getting freedom of voice and mobility. Acquiring decision making power was measured by the parameter namely decision-making ability on food consumption and small purchase (for example, dress), buying/selling property and adopting family planning choice. Contribution to family income \& control over assets was measured by spawning income and contribution to the family expenditures, gaining access to pure drinking water and hygiene/sanitation, deserving independent savings and acquiring household assets in her name. Getting freedom of voice and mobility was measured by selfdetermined polling decision, freedom of movement to public places without the permission of anybody etc. respectively by the women borrowers who spent five years in BRAC and ASA comparing with the nonborrowers who are not facilitated through any microcredit program. The following Table 1 narrates the indicator or variables that were considered to determine the impact of microcredit on the extent of empowerment of the women borrowers and non-borrowers.

Table 1: List of indicator or variables considered to determine the impact of microcredit on the extent of women-empowerment.

\begin{tabular}{|c|c|}
\hline Variables Cluster of Women Empowerment & Specific Variables of Women Empowerment \\
\hline $\begin{array}{l}\text { Psychological Empowerment*: } \\
\text { Acquiring decision making power in the } \\
\text { household activities. }\end{array}$ & $\begin{array}{l}\text { (a) Decision making ability on food consumption or a small } \\
\text { purchase (e.g. dress), } \\
\text { (b) Decision making ability to purchase major goods for the } \\
\text { household (e.g. TV) }\end{array}$ \\
\hline
\end{tabular}




\begin{tabular}{|c|c|}
\hline $\begin{array}{l}*(\text { The ability to make and influence process of } \\
\text { reaching decisions; i.e. the respondent is able to } \\
\text { make a small purchase, like a dress, without } \\
\text { consulting with her husband) }\end{array}$ & $\begin{array}{l}\text { (c) Decision making ability on buying/selling property, } \\
\text { (d)Adopting family planning decision, } \\
\text { (e) Choices a TV program in the presence of husband or other male } \\
\text { family members } \\
\text { (f) Decision to work outside of home } \\
\text { (g) Taking decision about children's schooling. }\end{array}$ \\
\hline $\begin{array}{l}\text { Economic Empowerment*: } \\
\text { Contribution to family income \& control over } \\
\text { assets and enjoying better facilities. }\end{array}$ & $\begin{array}{l}\text { (h)Spawning monthly income, } \\
\text { (i) Contribution to the family's monthly expenditures, } \\
\text { (j) Acquiring household assets in her name, }\end{array}$ \\
\hline $\begin{array}{l}* \text { (Attaining/ an attribute of an economic } \\
\text { good/wealth or enjoying better facilities) }\end{array}$ & $\begin{array}{l}\text { (l) Personally own property and/or valuables (e. g. jewelry) } \\
\text { (m) Gaining access to pure drinking water and hygiene /sanitation. }\end{array}$ \\
\hline $\begin{array}{c}\text { Social Empowerment*: } \\
\text { Getting freedom of voice, mobility and expression. } \\
* \text { (The freedom of Expression/Movement; i.e. the } \\
\text { respondent is able to visit the local market without } \\
\text { consulting with her husband or feels comfortable } \\
\text { expressing her opinion ) }\end{array}$ & $\begin{array}{l}\text { (o) Self-determined polling decision, } \\
\text { (p) Freedom of movement to public places without asking } \\
\text { permission of husband/ anybody etc. } \\
\text { (q) Feels comfortable expressing her opinion in the presence of her } \\
\text { husband or other family members }\end{array}$ \\
\hline
\end{tabular}

Contribution to family income and control over assets was measured by spawning income and contribution to the family expenditures, gaining access to pure drinking water and hygiene/sanitation, deserving independent savings and acquiring household assets in her name.

\section{Analysis of Data}

Data of the respondents were analyzed by Mean Value Analysis and Statistical Analysis. Mean Value and Standard deviation of the variables have been deter-mined to evaluate two situations on 'before' and 'after' of the microcredit recipients/borrowers and ' 5 years back' and 'current year' of non-borrowers from the study areas to recognize the level of empowerment and improvement of living standard.

\section{RESULTS:}

\section{Descriptive statistics: Demographic characteristics of the respondent}

Among the 100 microcredit borrowers, 51 from BRAC and 49 from ASA were selected for this survey who received credit from 10 branches of BRAC and ASA respectively. For making comparison between borrowers and non-borrowers a sample of 50 nonborrowers were also selected from that area for analysis. Baseline demographic data of the borrowers and non-borrowers were collected to depict the characteristics of respondents such as age, marital status, education, factor influencing credit decision, purpose of receiving credit by the respondent that are presented below in Table 2.

Table 2: Demographic Characteristics of the respondent borrowers and non-borrowers \& purpose of receiving credit by the women borrowers in the study areas.

\begin{tabular}{|c|c|c|c|}
\hline Demographic Characteristics & Parameter (Range) & Percentage of Borrowers & Percentage of Non-Borrowers \\
\hline Age Group & $0-30$ & 35 & 32 \\
\hline & $31-40$ & 38 & 28 \\
\hline & $41-50$ & 27 & 02 \\
\hline & 51 above & 0 & 90 \\
\hline Marital Status & Married & 93 & 02 \\
\hline & Unmarried & 01 & 04 \\
\hline & Divorced & 02 & 04 \\
\hline & Widow & 04 & 20 \\
\hline & Illiterate & 5 & 35 \\
\hline & Can sign only & 32 & 18 \\
\hline
\end{tabular}




\begin{tabular}{|l|c|c|c|}
\hline & NGO personal & 25 & $\mathrm{n} / \mathrm{a}$ \\
\hline & Sr. Borrowers & 20 & $\mathrm{n} / \mathrm{a}$ \\
\hline & Neighbors /Others & 05 & $\mathrm{n} / \mathrm{a}$ \\
\hline
\end{tabular}

Economic analysis - Impact of microcredit on women empowerment

This study defines women empowerment as the process in which women challenge existing norms of the society, in which they live, to improve their wellbeing. Furthermore, in Table 3, this study defines women's empowerment within four subgroups: (a) Decision-making power in the household activities, (b) Contribution to Family Income \& Control over Assets, (c) Freedom of Voice, and (d) Mobility. Functioning variables considered in the study were decision making ability on Food consumption, decision making ability on buying/selling property, adopting family microcredit borrowers and non-borrower groups of women (Akter, 2020).

Table 3: Impact of microcredit on women empowerment.

\begin{tabular}{|c|c|c|}
\hline & $\begin{array}{l}\text { Microcredit borrowers } \\
\text { (Mean) }\end{array}$ & $\begin{array}{l}\text { Non-borrowers } \\
\text { (Mean) }\end{array}$ \\
\hline \multicolumn{3}{|c|}{ Decision: making indicators } \\
\hline Make a small purchase (e.g. dress) without consulting husband & 0.29 & 0.16 \\
\hline Have a say in whether to purchase major goods for the household (e.g. TV) & 0.76 & 0.64 \\
\hline Have a say in whether to work outside home & 0.14 & 0.05 \\
\hline Have a say in how many children to have & 0.9 & 0.8 \\
\hline Have a say in whether to buy or sell property & 0.48 & 0.34 \\
\hline Have a say in whether or not to send children to school & 0.97 & 0.78 \\
\hline \multicolumn{3}{|l|}{\begin{tabular}{|c|} 
Ownership of assets indicators \\
\end{tabular}} \\
\hline Landownership in own name & 0.06 & 0.02 \\
\hline Personally own property and/or valuables (eg: jewelry) & 0.59 & 0.55 \\
\hline Have independent savings & 0.5 & 0.02 \\
\hline \multicolumn{3}{|l|}{ Voice indicators } \\
\hline Comfortable giving opinion in the presence of husband & 0.82 & 0.69 \\
\hline \multicolumn{3}{|l|}{ Mobility indicators } \\
\hline $\begin{array}{c}\text { Comfortable going to the local market without asking permission from } \\
\text { husband or other family member }\end{array}$ & 0.17 & 0.11 \\
\hline $\begin{array}{l}\text { Comfortable going to the neighboring village without asking for } \\
\text { permission from husband or other family member }\end{array}$ & 0.02 & 0.01 \\
\hline
\end{tabular}

Obviously, successful utilization of borrowed money is expected to make a positive impact on the income of a borrower. The analysis of data affirmed to this fact. As described in Table 4, it was found from the survey that average monthly income of the borrowers before taking credit was BDT 13500 and after using credit, it increased to BDT 22132 and average monthly income of the non-borrowers on ' 5 years back' was BDT 10000 and 'currently' it stood BDT 14912. From Table 4, it is found that average monthly expenditure of borrowers before credit was BDT 9100 and after using credit, it increased to BDT 19,396 and average monthly expenditure of the non-borrowers on '5 years back' was BDT 12000 and currently it stood BDT 12050. Table 4 also revealed the changes of other variables explicitly homestead, agricultural land, monthly expenditure, food expenditure, education expenditure, health expenditure, clothing and health \& nutrition on 'before credit' and 'after credit' for borrowers \& '5 years back' and 'currently' for non-borrowers. The average homestead areas of borrowers were 16.90 decimals and 24.39 decimals before and after using loans respectively. After 5 years the result has been changed for non-borrowers also, but not significantly.

Table 5 portrayed the comparison of family's monthly income 'before' and 'after' of consuming credits by the borrowers and income earned 'five years back' and 'current' income by the non-borrowers. Table 5 showed that before using credit 53 percent borrowers have up to 19 decimals homestead, 18 percent have between 20-39 decimals, 8 percent have 40 to 59 de- 
cimals, and 1 percent have 60 and above decimals and 20 percent were completely landless and ' 5 years back' 36 percent non-borrowers had no land, 44 percent had up to 19 decimals, 10 percent non-borrowers had between 20 to 39 decimals, 6 percent had bet- ween 40 to 59 decimals and 4 percent non-borrowers had 60 decimals and above ; but the scenario of the poor women have been changed after joining MFI's (BRAC and ASA) due to the impact of microcredit consumption.

Table 4: Average value of the variables of the Women borrowers and Non-borrowers.

\begin{tabular}{|c|c|c|c|c|}
\hline \multirow{2}{*}{ Variables } & \multicolumn{2}{|c|}{ Average of the borrowers } & \multicolumn{2}{c|}{ Average of the Non-borrowers } \\
\cline { 2 - 5 } & Before credit & After credit & 5 years back & Currently \\
\hline Monthly income & BDT13500 & BDT 22132 & BDT 10000 & BDT 14912 \\
\hline Homestead & 16.90 decimal & 24.39 decimal & 16.30 decimal & 7.08 decimal \\
\hline Agricultural land & 19.50 decimal & 25.62 decimal & 19.10 decimal & 8.38 decimal \\
\hline Monthly expenditure & BDT9100 & BDT 19396 & BDT 12000 & BDT 12050 \\
\hline Food expenditure & BDT 6950 & BDT 11197 & BDT 9300 & BDT 8184 \\
\hline Education expenditure & BDT 900 & BDT 1818 & BDT 1,050 & BDT 964 \\
\hline Health expenditure & BDT 1200 & BDT 2736 & BDT 1,800 & BDT 1804 \\
\hline Clothing & BDT 750 & BDT 1714 & BDT 900 & BDT 1512 \\
\hline Health and nutrition & BDT 1420 & BDT 2505 & BDT 1700 & BDT 1574 \\
\hline
\end{tabular}

Table 5: Comparison of different income and related variables before and after of consuming credits by the borrowers and current and five years back by the non-borrowers.

\begin{tabular}{|c|c|c|c|c|c|}
\hline & & \multicolumn{2}{|c|}{ Percentage of borrowers } & \multicolumn{2}{|c|}{ Percentage of non-borrowers } \\
\hline Variables & Particulars (Ranges) & \multicolumn{2}{|c|}{ Before credit After credit } & \multicolumn{2}{|c|}{5 years back Currently } \\
\hline \multirow{6}{*}{ Monthly income (BDT) } & $0-10000$ & 50 & 11 & 62 & 40 \\
\hline & $10001-20000$ & 26 & 35 & 30 & 38 \\
\hline & $20001-30000$ & 13 & 31 & 4 & 14 \\
\hline & $30001-40000$ & 11 & 21 & 4 & 8 \\
\hline & $40001-50000$ & 0 & 0 & 0 & 0 \\
\hline & 50001 above & 0 & 2 & 0 & 0 \\
\hline \multirow{5}{*}{$\begin{array}{l}\text { Area of Homestead of } \\
\text { the Borrowers (decimal) }\end{array}$} & No land & 20 & 5 & 36 & 40 \\
\hline & $0-19$ & 53 & 45 & 44 & 56 \\
\hline & $20-39$ & 18 & 30 & 10 & 4 \\
\hline & $40-59$ & 8 & 15 & 6 & 0 \\
\hline & 60 above & 1 & 5 & 4 & 0 \\
\hline \multirow{7}{*}{$\begin{array}{c}\text { Area of Cultivable land } \\
\text { (decimal) }\end{array}$} & No land & 73 & 49 & 60 & 64 \\
\hline & $0-19$ & 5 & 10 & 18 & 22 \\
\hline & $20-39$ & 10 & 15 & 10 & 8 \\
\hline & $40-59$ & 2 & 6 & 4 & 4 \\
\hline & $60-79$ & 5 & 7 & 4 & 2 \\
\hline & $80-99$ & 4 & 8 & 2 & 0 \\
\hline & 100 above & 1 & 5 & 2 & 0 \\
\hline
\end{tabular}

The percentage of respondents holding an area of 2039 decimals homestead increased from 18 percent to 30 percent, holding an area of $40-59$ decimals increased from 8 percent to 15 percent and respondent holding land of 60 decimals and above increased from 1 percent to 5 percent found in Table 5. Table 6 portrayed the comparison of family's monthly expenditure and other expenditure variables 'before' and 'after' of consuming credits by the borrowers and 'five years back' and 'current' expenditure by the non-borrowers. Table 6 showed that 81 percent of the borrowers had monthly education expenses up to BDT 1500 and the remaining 19 percent spent above UniversePG I www.universepg.com
BDT 1500 per month for education. This was the position of the respondents before credit received. It has been found that this position changed after the use of the credit by the borrowers. It was found that after credit the percentage of the borrowers having education expenses up to BDT 1500 per month decreased to 39 percent and the percentage of borrowers having expenses more than BDT 1500 increased to 61 percent. It was calculated from the Table 1 that before credit average education expenditure was BDT 900 and after credit average education expenditure reached to BDT 1818 for the women borrowers. 
Table 6: Comparison of different expenditure variables and degree of living standard before and after of consuming credits by the borrowers and current and five years back by the non-borrowers.

\begin{tabular}{|c|c|c|c|c|c|}
\hline \multirow{2}{*}{ Variables } & \multirow{2}{*}{ Particulars } & \multicolumn{2}{|c|}{ Percentage of borrowers } & \multicolumn{2}{|c|}{ Percentage of non-borrowers } \\
\hline & & Before credit & After credit & 5 years back & Currently \\
\hline \multirow{4}{*}{$\begin{array}{l}\text { Monthly Total } \\
\text { expenditure (BDT) }\end{array}$} & $0-10000$ & 64 & 8 & 48 & 54 \\
\hline & $10001-20000$ & 32 & 53 & 40 & 42 \\
\hline & $20001-30000$ & 3 & 32 & 6 & 2 \\
\hline & $30001 \&$ above & 1 & 5 & 6 & 2 \\
\hline \multirow{4}{*}{$\begin{array}{l}\text { Food expenditure } \\
\text { (monthly) (BDT) }\end{array}$} & $0-5000$ & 40 & 5 & 12 & 20 \\
\hline & $5001-10000$ & 38 & 36 & 54 & 60 \\
\hline & $10001-15000$ & 15 & 33 & 20 & 10 \\
\hline & $15001 \&$ above & 7 & 26 & 14 & 10 \\
\hline \multirow{5}{*}{$\begin{array}{l}\text { Education Expenditure } \\
\text { (monthly) (BDT) }\end{array}$} & $0-500$ & 43 & 13 & 48 & 40 \\
\hline & $501-1000$ & 16 & 6 & 8 & 22 \\
\hline & $1001-1500$ & 22 & 20 & 10 & 16 \\
\hline & $1501-2000$ & 6 & 4 & 4 & 4 \\
\hline & $2001 \&$ above & 13 & 57 & 30 & 18 \\
\hline \multirow{7}{*}{$\begin{array}{l}\text { Health expenditure } \\
\text { (monthly) (BDT) }\end{array}$} & $0-1000$ & 56 & 22 & 30 & 28 \\
\hline & $1000-2000$ & 26 & 25 & 24 & 36 \\
\hline & $2000-3000$ & 13 & 17 & 26 & 24 \\
\hline & $3000-4000$ & 4 & 15 & 8 & 6 \\
\hline & $4000-5000$ & 0 & 4 & 8 & 4 \\
\hline & $5000-6000$ & 0 & 5 & 2 & 2 \\
\hline & $6001 \&$ above & 1 & 12 & 2 & 0 \\
\hline \multirow{5}{*}{$\begin{array}{l}\text { Cloth Expenditure } \\
\text { (monthly) (BDT) }\end{array}$} & $0-1000$ & 87 & 55 & 78 & 42 \\
\hline & $1001-2000$ & 10 & 22 & 16 & 42 \\
\hline & $2001-3000$ & 0 & 7 & 2 & 8 \\
\hline & $3001-4000$ & 0 & 3 & 0 & 0 \\
\hline & $4001-5000$ & 0 & 5 & 0 & 4 \\
\hline \multirow{6}{*}{$\begin{array}{c}\text { Condition of } \\
\text { Dwelling House }\end{array}$} & No house & 25 & 14 & 0 & 0 \\
\hline & clay made & 6 & 2 & 6 & 6 \\
\hline & thatch made & 19 & 2 & 4 & 4 \\
\hline & Clay and Tin & 40 & 60 & 62 & 60 \\
\hline & Semi paka & 7 & 19 & 20 & 22 \\
\hline & building & 3 & 3 & 6 & 6 \\
\hline \multirow{6}{*}{$\begin{array}{c}\text { Total Nutrition } \\
\text { Expenditure } \\
\text { (sum of fish, meat and milk } \\
\text { (monthly) (BDT) }\end{array}$} & $0-1000$ & 50 & 19 & 36 & 40 \\
\hline & $1001-2000$ & 25 & 20 & 30 & 44 \\
\hline & $2001-3000$ & 15 & 32 & 20 & 12 \\
\hline & $3001-4000$ & 5 & 15 & 8 & 2 \\
\hline & $4001-5000$ & 3 & 10 & 4 & 2 \\
\hline & $5001 \&$ above & 2 & 4 & 2 & 0 \\
\hline \multirow{2}{*}{$\begin{array}{l}\text { Choice of Hygienic } \\
\text { Sanitation }\end{array}$} & Yes & 56 & 93 & 52 & 70 \\
\hline & No & 44 & 7 & 48 & 30 \\
\hline \multirow{2}{*}{$\begin{array}{l}\text { Choice of Pure } \\
\text { Drinking Water }\end{array}$} & Yes & 61 & 97 & 60 & 70 \\
\hline & No & 39 & 3 & 40 & 30 \\
\hline
\end{tabular}

In Table 6, it is found that 96 percent of the borrowers incurred monthly expenditure up to 20 thousand and the remaining 4 percent had expenditures above 20 thousand taka per month before receiving credit. The position has been changed after using credit. It was observed that the percentage of the borrowers having expenses up to BDT 20 thousand per month decreased to 61 percent and borrowers having expenses more than BDT 20 thousand increased to 37 percent. On the other hand, on ' 5 years back' 66 percent non-borrower spent for education up UniversePG I www.universepg.com to BDT 1500 and remaining 34 percent of the nonborrower spent above BDT 1500 for education purpose and currently the percentage of education expenditure up to BDT 1500 per month increased to 78 percent for non-borrowers. From Table 6, it is found that 95 percent of the respondents incurred monthly health expenditure up to BDT 3000 and remaining 5 percent of the respondents (borrowers) spent above BDT 3,000 per month before receiving credit. But after receiving credits this situation has been changed. After credit the percentage of the borrower having 
health expenses up to BDT 3000 decreased to 64 percent and the percentage of health expenditure above BDT 3000 increased to 36 percent. On the other hand, from Table 3, it is observed that 5 years back 80 percent non-borrowers' monthly health expenditure was BDT up to 3000 and the remaining 20 percent of the non-borrowers spent more than BDT 3000. But currently the position has been changed nominally. Currently, the percentage of health expenditure up to BDT 3000 increased to 88 percent and the percentage of health expenditure above BDT 3,000 decreased to 12 percent. On ' 5 years back' average health expenditure was BDT 1800 and 'currently' it reached to BDT 1804 respectively for non-borrower respondents as reported in Table 1. Therefore, it seemed that borrowers were able to increase their health expenditure by the fund generated from utilization of microcredit. Table 3 also revealed that before taking credit, 40 percent borrowers lived in clay and tin made house but after credit the percentage of the dweller of clay and tin made house increased to 60 percent. Before credit 7 percent credit receivers lived in semi paka house but after credit borrowers having semi paka house increased to 19 percent respectively. After receiving microcredit, respondents were found aware of their health, sanitation and pure drinking water. They got credit to increase their level of living standard. It is evident that before credit 56 percent borrowers found to use hygienic sanitation and after credit use of hygienic sanitation of borrower increased to 93 percent. But in case of non-borrowers it is observed that ' 5 years back' 52 percent non-borrower were found to use hygienic sanitation and currently 70 per-cent nonborrowers found to habit hygienic sanitation as showed in Table 6. From Table 6, it is also observed that before receiving credit, 61 percent borrowers were cast off pure drinking water and after receiving credit 97 percent borrowers were found to drink pure drinking water. But in case of non-borrowers it is found that on ' 5 years back' 60 percent non-borrowers were found to use pure drinking water and 'currently' 70 percent non-borrowers were found to use pure drinking water respectively.

\section{Econometric analysis - Chi-square test and ANO- VA}

To affirm the results found from tabular analysis, econometric analysis such as Chi-Square test and ANOVA have been used to evaluate the association of variables and extent of contribution within the variables. Being consistent with the study following hypothesis for chi-square was formulated. Table 7 revealed that calculated chi-square value $\left(\chi^{2}=0.043\right)$ for income reported less than 0.05 . It implies that the impact of microcredit on the level of income is significant at the 5 percent level of significance. Thus, microcredit has a positive impact on income. It is also evident from the Table 4 that in cases of acquiring agricultural land, monthly expenditure, food expenditure, health expenditure, condition of dwelling house and pure drinking water, calculated chi-square values were found as $\chi^{2}=0.004, \chi^{2}=0.000, \chi^{2}=0.006, \chi^{2}=0$. 005, $\chi^{2}=0.007, \chi^{2}=0.0001, \chi^{2}=0.001$ respectively which were less than 0.05 that testimony the impact of microcredit on the agricultural land, monthly expenditure, food expenditure, health expenditure, condition of dwelling house and pure drinking water were significant at the 5 percent level of significance.

However, in the case of homestead, calculated $\chi^{2}$ value $\left(\chi^{2}=1.679\right)$ was more than 0.05 which implied that the impact of microcredit on the level of homestead acquisition was not significant at 5 percent level of significance. It is also found from Table-4 that calculated value of clothing, health and nutrition and hygienic sanitation status were $\chi^{2}=0.581, \chi^{2}=0.161$ and $\chi^{2}=0.112$ respectively which meant impact of microcredit on homestead, clothing, health and nutrition and hygienic sanitation were not significant at the 5 percent level of significance.

Table 7: Results of Chi-square and ANOVA test.

\begin{tabular}{|c|c|c|c|c|c|c|}
\hline & \multicolumn{2}{|c|}{ Results : Chi-square } & \multicolumn{4}{c|}{ Results : ANOVA } \\
\hline & $\begin{array}{c}\text { Calculated } \\
\text { value of } \chi 2\end{array}$ & $\begin{array}{c}\text { Significance of } \\
\text { Input data }\end{array}$ & $\begin{array}{c}\text { Calculated } \\
\text { F values }\end{array}$ & $\begin{array}{c}\text { Critical } \\
\text { F values }\end{array}$ & $\begin{array}{c}\text { P values } \\
\text { Significance of } \\
\text { input }\end{array}$ \\
\hline Income & 0.043 & Sig & 21.015 & 3.905 & $0.000^{*}$ & Sig \\
\hline Homestead & 1.679 & Not sig & 48.342 & 3.905 & $0.000^{*}$ & Sig \\
\hline Agricultural land & 0.004 & Sig & 11.591 & 3.905 & $0.000^{*}$ & Sig \\
\hline Monthly expenditure & 0.000 & Sig & 46.149 & 3.905 & $0.000^{*}$ & Sig \\
\hline Food expenditure & 0.006 & Sig & 23.184 & 3.905 & $0.000^{*}$ & Sig \\
\hline Education expenditure & 0.005 & Sig & 33.945 & 3.905 & $0.000^{*}$ & Sig \\
\hline
\end{tabular}




\begin{tabular}{|c|c|c|c|c|c|c|}
\hline Health expenditure & 0.007 & Sig & 8.907 & 3.905 & $0.003^{* *}$ & Sig \\
\hline Clothing & 0.581 & Not sig & 0.3439 & 3.905 & 0.55 & Not sig \\
\hline Health and nutrition & 0.161 & Not sig & 21.523 & 3.905 & $0.000^{*}$ & Sig \\
\hline Condition of dwelling house & 0.0001 & Sig & - & - & - & - \\
\hline Hygienic sanitation & 0.112 & Not sig & - & - & - & - \\
\hline Pure drinking water & 0.001 & Sig & - & - & - & - \\
\hline
\end{tabular}

*denotes significant at less than 1 percent; ** Significant at less than 5 percent.

The statistical tool of ANOVA was used to describe the impact of microcredit on borrower to evaluate its poverty alleviation role. It is indicated that microcredit has a positive impact on the level of income for the borrowers. From Table 7, it is observed that calculated value of $\mathrm{F}$ for homestead, agricultural land, monthly expenditure, food expenditure, educational expenditure, health expenditure and health and nutrition were found as $48.342,11.591,46.149,23.184$, $33.945,8.907$ and 21.523 respectively. Thus, it can be said that microcredit has a positive impact on homestead, agricultural land, monthly expenditure, food expenditure, educational expenditure, health expenditure and health \& nutrition. Contrary, in the case of clothing, calculated F value was 0.3439 means the impact of microcredit on clothing was not significant at 5 percent level of significance. How-ever, it is found that microcredit has a negative impact on clothing. It is concluded from the above analysis that microcredit seemed to have a significant positive effect on the income, expenditure and other variables of level of living standard.

\section{DISCUSSION:}

The study has represented the real features of rural Bangladeshi women. Microcredit programs are provided to the village women where different size of loans helps develop their economic condition. This study has reviewed the microcredit program initiated by BRAC and ASA in some selected areas of Chattogram district and attempted to assess the efficiency of microcredit in reducing poverty in the study areas. According to the socio demographic profile, majority falls into the age group of 25 to 40 years. This fact suggested that the credit program is targeted towards an actively working age group. It is found that housewives get priority in credit sanction. The literacy rate of the respondents of the study areas is very poor. Only 27 percent can sign only, 20 percent is literate and there is no graduate at all. Most of the borrowers have no idea about service charge; they only can sign security paper at the time of borrowing. Majority of them are married and when they face some financial problem their husband encourages them to take loan from the MFIs. According to this study, many borrowers obtained loans from more than one microfinance institution. Generally, the study showed that microcredit contributed to the reduction of poverty. Other hypotheses, however, had a lesser effect. Study results demonstrate that microcredit programs have a positive impact on income levels. Income and microcredit are positively correlated. In addition, the tabular analysis shows that the borrower's average income is greater than the non-borrowers' income, indicating that the borrower is in a better financial position. According to Chowdhury et al. (2005), Khandker (1998), Samer et al. (2015), Khan and Karim, (2016), these results are sustained. The study also reveals that there is no impact on homestead gaining or acquisition due to participation in microcredit programs. If there are microcredit programs, then there would be an increase in household expenditure on household items. The result reveals a positive effect of microcredit programs on expenditure of household items. The study discovered that microcredit programs lead to an increase of the consumption of the food items. Results reveal positive relationship between food consumption and expenditure and microcredit programs which is also aligned with the previous study (Kondo et al., 2008). Moreover, microcredit programs have a positive impact on the level of children education. The results reveal a significant and positive relationship between children education and microcredit participation. These results are consistent with the findings of previous studies (Neponen, 2003 \& Sengsourivong, 2006) although the findings are against several studies (Coleman, 1999 and Kondo, 2007). Furthermore, microcredit has a positive impact on health expenditure. This result is also consistent with previous study (Islam et al., 2014) although shows a negative impact on clothing. Women health are getting better (Sarkar and Dhar, 2017) even during the current pandemic situation (Dhar et al., 2020; Ayittey et al., 2020) and financial constrains (Chowdhury and Dhar, 2012; Chowdhury et al., 2021) in Bangladesh (Absar et al., 2021; Dhar 
et al., 2021). From this study it is found that there is a positive impact on the condition of dwelling house. That means microcredit improved house condition of the borrowers after taking loans. Tenth and eleventh hypothesis of chi-square reveals that there is no impact of microcredit on health and nutrition and hygienic sanitation. Findings of hygienic sanitation are also similar to the previous study (Khanom, 2014). In case of pure drinking water, the study discovered that there is a positive impact of microcredit on intake of pure drinking water by the dwellers of the investigated areas which is supported by the study of Khanom (2014). From the study, it is also found that the average medical expenditure increases than before.

Women empowerment situation is improved after taking credit. This result is also supported by previous study of Banerjee et al. (2015). From the study, it can be ascertained that there is a significant difference between the borrowers and non-borrowers in respect of income, homestead, agricultural land, monthly expenditure, food expenditure, education expenditure, health expenditure, condition of dwelling house, health and nutrition, hygienic sanitation, and pure drinking water. Calculated value of $\mathrm{F}$ for income was 21.015 which were significant at 5 percent level. Therefore, the hypothesis H0-1 was examined. It indicated that microcredit has a positive impact on the level of income for the borrowers. From Table 7, it is found that calculated value of $\mathrm{F}$ for homestead, agricultural land, monthly expenditure, food expenditure, educational expenditure, health expenditure and health and nutrition are reported as 48.342, 11.591, 46.149, 23. $184,33.945,8.907$ and 21.523 respectively. Thus, it can be summarized that microcredit has a positive impact on homestead, agricultural land, monthly expenditure, food expenditure, educational expenditure, health expenditure and health and nutrition which is revealed from study of Khandker et al. (2015). Only in the case of clothing there is no significant difference found between borrowers and non-borrowers which enlighten no significant effect of microcredit on clothing. However, in summery it is winded up from the above analysis that microcredit seemed to have a significant positive effect on the income, expenditure, and level of living standard. Findings of the study disclose that borrowers can improve their level of living standard by generating more income and upgrading consumption expenditure due to receipt and proper utilization of microcredit. Hence, positive impact of microcredit on poverty alleviation UniversePG I www.universepg.com is further corroborated from the overall findings of the present study.

\section{Recommendation}

This study has exemplified the impacts of microcredit operations of BRAC and ASA on the poverty alleviation of women borrowers. Findings stemmed from the analysis of the data of the study areas determined that the overall impacts of microcredit of BRAC and ASA are positive on the livelihood of the poor women. In some cases, the impact is limited or no significant due to some hindrance on the way of the development of microcredit industry. To overcome the drawbacks of the development process and to achieve a sustainable economic growth, the following recommendations should be taken into due consideration.

\section{Proper product design $\&$ innovations}

Due to lack of proper designing most of the innovation of microcredit products are unreachable to the poor and are not in practiced. Therefore, the MFI's should design the products in such a simple way according to the diverse financial needs of the poor and keeping in mind the socio economic, political, geographical environment of the impact areas, status, needs and beliefs of its population so that the poor can easily understand and can avail the facilities.

\section{Research and training}

Research and training on different contemporary issues and ideas related to the growth and development of microcredit sector, knowledge imparts, traits of diversified product portfolio, impact assessment, regional and international co-operation, integration of policy, regulation \& implementation are needed extensively.

\section{Expanding Programs for the Ultra-poor}

Reducing ultra-poverty is the number one target of Millennium Development Goals (MDG). Considering the severity of poverty, attempts taken by the MFIs are not enough to cope with the extreme poverty situation. National-level strategies and activities should also be taken by giving prime importance on extreme poverty reduction.

\section{Reaching Economically Backward Region}

Expansion of outreach of MFIs/NGOs should effecttively be reached the people of economically backward regions of the country. Being the poor are scattered throughout the remote geographical areas, the MFIs should expand their network and jurisdiction into the extremely rural part across the country to include the most vulnerable community. 
Flexible Terms \& Condition of the Credit Product

Terms and condition of the microcredit facilities/ eligibility of the borrowers should be of flexible regarding interest rate, first maximum loan amount, installment size and duration allowed between two consecutive installments (i.e., monthly). Eligibility of the credit recipients should be irrespective of gender, age and marital status because poor men also need credit to generate income or to develop entrepreneurship. On the other hand, unmarried young women have more potential to build up entrepreneurship.

\section{Attracting More Funds}

More funds are needed to fulfill the loan requirement of the bulk number of rural poor. Fund should be raised by voluntary and compulsory savings of NGOs/MFIs, attracting funds from banks, increasing size of wholesale funds from PKSF, issuing IPO at capital markets and by convincing the international donor community.

\section{Strengthening Regulation and Supervision}

Cooperative Development Foundation (CDF) and Palli Karma-Sahayak Foundation (PKSF) are the regulatory bodies for microcredit sector. PKSF, in the last decade, has prepared a number of policy guidelines and standards for its Partner Organizations (POs) and for the microcredit sector to govern the microcredit practices. Microcredit Regulatory Authority Act-2006, Companies Act-1913, Trusts Act1882, Charitable and Religious Trust Act-1920 and Cooperative Societies Ordinance-1984 have created the present regulatory framework for this industry. But till now Bangladesh is unable to prepare a National Microcredit Policy.

A National Microcredit Policy framework is urgently needed to guide the sector rigorously. Supervisory approaches should also be strengthened to make MFIs more transparent and ac-countable.

\section{Roles of Government and Funding Agencies}

Governments must continue their focus on financial inclusion as a key area of policy as in the Sixth Five Year plan (SFYP). The Government should provide sophisticated policy environment, intervene into the matter that distort the market for microcredit, focus on grant, create new legal structure for commercial MFIs, and adopt appropriate regulation and supervision for microcredit and to improve the framework time to time aligned with technological advancement for secured transactions.

\section{Other voluntary services}

Besides Microcredit operation, concealing, literacy program, awareness building program should be provided to a larger extent to the poor women so that they can utilize the credit properly and be able to help themselves toward a decent lifestyle.

\section{Responsibility on the Part of Borrower}

For sustainable microcredit development, the responsibilities of borrower community are also of importance. The borrower should repay the loan timely as per the terms and condition. This is needed for the sustainability of the loan giving institution to have a long continuance so that more and more individuals can avail the facility. Individual borrower or household should be free from overlapping or multiple borrowing. Borrower should also use the credit in the productive income generating activities and should not divert the fund to unproductive purposes.

\section{CONCLUSION:}

In this study, various dimensions of livelihood in rural Chattogram district (Hathazari, Sitakunda and Mirsharai) were assessed as a result of borrowing from BRAC and ASA. Moreover, this study shows that BRAC and ASA microcredit programs help improve the socioeconomic status of borrower participants. Our results recommend that microcredit has a positive impact and significant contributions to household income and consumption. These results are in line with previous studies and enumerate that microcredit creates positive effects for the poor. Microcredit opens an opportunity for women borrowers to play significant role in the economic development of the country. Since independence MFIs (BRAC, ASA and the like) play a vital role to improve the poverty situation of Bangladesh. From the present study, it can be apprehended that BRAC and ASA microcredit have a positive impact on monthly income, monthly expenditure on education, health expenditure, condition of dwelling house, gaining homestead and agricultural land etc. BRAC and ASA provide their services only to the poor women. BRAC and ASA mainly involve with the practice of microcredit (loan products) only in the study area. The performance and achievement of BRAC and ASA in Chattogram is of great importance in the context of alleviating poverty of poor women. More research needs to be carried on the impact of microcredit on poverty alleviation through other MFIs also in Bangladesh to achieve our MDG. 


\section{ACKNOWLEDGEMENT:}

To begin, I wish to thank Almighty Allah for keeping me swell enough to carry out this research. All respondents who took the time to complete the survey, as well as all individuals who contributed directly or indirectly to the study's preparation, are acknowledged.

\section{CONFLICTS OF INTEREST:}

The authors have no conflicts of interest in publishing this research study.

\section{REFERENCES:}

1) Absar, M. M. N., Dhar, B. K., \& Emran, M. (2021). Sustainability disclosures in emerging economies: Evidence from human capital disclosures on listed banks' websites in Bangladesh. Business and Society Review, 126(3), 363378. https://doi.org/10.1111/basr.12242

2) Akter S. (2020). Women employment opportunity on SMEs sector: Bangladesh perspective, Int. J. Manag. Account. 2(5), 105-118. https://doi.org/10.34104/ijma.020.01050118

3) Alnaa, S. E., \& Ahiakpor, F. (2015). Synthesis of Microfinance and Technical Efficiency: Implications for Poverty Reduction in Ghana. Research in Applied Economics, 7(1), 13-25.

http://dx.doi.org/10.5296/rae.v7i1.6599

4) Association for Social Advancement, (2019). Annual Report- 2019. Dhaka, Bangladesh, Association for Social Advancement (ASA).

5) Awan, A.G. \& Juiya, M. J. L. (2015). Role of microcredit in poverty alleviation: evidence from Pakistan. American J. of Trade and Policy, 2(1), 37-44. http://dx.doi.org/10.18034/ajtp.v2i1.558

6) Ayittey, F. K., Dhar, B. K., and Chiwero, N.B. (2020). Gendered burdens and impacts of SARSCoV-2: a review. Health Care for Women International, 41(11-12), 1210-1225. https://doi.org/10.1080/07399332.2020.1809664

7) Banerjee, A., Duflo, E., Glennerster, R., \& Kinnan, C. (2015). The miracle of microcredit: Evidence from a randomized evaluation. American Economic J.: Applied Economics, 7(1), 2253. http://dx.doi.org/10.1257/app.20130533

8) Bangladesh Rural Advancement Committee, (2019). Annual Report-2019. Dhaka: Bangladesh. Bangladesh Rural Advancement Committee (BRAC).

9) Basak S. (2021). Factors affecting work-life balance of women in Bangladesh: a study during
COVID-19 pandemic, Can. J. Bus. Inf. Stud., 3(3), 38-48.

https://doi.org/10.34104/cjbis.021.038048

10) Berglund, K. E. (2007). The Effect of Microfinance on the Empowerment of Women and its Societal Consequences: A study of women selfhelp group members in Andhra Pradesh. Uppsala University, 1-91.

https://www.diva-portal.org/smash/record.jsf?pid= diva2\%3A131654\&dswid=-3007

11) Browning, M. and Chiappori, P.A. (1998). Efficient Intra-Household Allocations: A General Characterization and Empirical Tests, Econometrica, 66, 1241-78.

https://doi.org/10.2307/2999616

12) Chowdhury, E. K., Khan, I. I., \& Dhar, B. K. (2021). Catastrophic impact of Covid-19 on the global stock markets and economic activities. Business and Society Review, 1-16. https://doi.org/10.1111/basr.12219

13) Chowdhury, M. J. A., \& Wright, R. E. (2005). The impact of micro-credit on poverty: evidence from Bangladesh. Progress in Development studies, 5(4), 298-309. https://doi.org/10.1191/1464993405ps116oa

14) Chowdhury, R. and Dhar, B. K. (2012). The Perspective of Loan Default Problems of the Commercial Banking Sector of Bangladesh: A Closer looks into the Key Contributory Factors. University of Science and Technology Annual (USTA), 18(1), 71-87. https://doi.org/10.6084/m9.figshare.16760746.v1

15) Coleman, B. E. (1999). The impact of group lending in Northeast Thailand. Journal of Development Economics, 60(1), 105-141. https://doi.org/10.1016/S0304-3878(99)00038-3

16) Crowley, S. S., Rahat, A.W.K., Amit. H. M., Dhar, B. K. (2020). Impact of Accountability in Social Media on Customer Satisfaction in Online Retail Businesses of Bangladesh. Advances in Management, 13(4), 24-29. https://doi.org/10.6084/m9.figshare.16821448.v1

17) Dhar, B. K., Ayittey, F. K., \& Sarkar, S. M. (2020). Impact of COVID-19 on Psychology among the University Students. Global Challenges, 4(11), 2000038. https://doi.org/10.1002/gch2.202000038

18) Dhar, B. K., Masruki, R., \& Absar, M. M. N. (2017). Impact of Islamic human resource practices on organizational performance through 
organizational commitment in the banking sector of Bangladesh. In $7^{\text {th }}$ Islamic Economic System Conference (iEcons), Muscat, Oman.

19) Dhar, B. K., Sarkar, S. M., \& Ayittey, F. K. (2021). Impact of social responsibility disclosure between implementation of green accounting and sustainable development: A study on heavily polluting companies in Bangladesh. Corporate Social Responsibility and Environmental Management.

https://doi.org/10.1002/csr.2174

20) Dhar, B. K, Mahazan, M. and Farid, A.S. (2020). Overcoming Unemployment through Vocational Education: The Role of Counselors in China. Adv. in Management, 13(3), 22-25. https://doi.org/10.6084/m9.figshare.16760509.v1

21) Dhar, B.K. (2019). The Impact of Intellectual Capital on Organizational Performance in the Banking Sector of Bangladesh (Doctoral dissertation, Universiti Sains Islam Malaysia). https://doi.org/10.13140/RG.2.2.26809.19047

22) Dhar, B.K. (2020). Impact of COVID-19 on Chinese Economy. Econ. Affairs, 9(3/4), 23-26. https://doi.org/10.6084/m9.figshare.16761442.v1

23) Dhar, B.K. and Mutalib, M. (2020). Leadership of Xi Jinping behind Unstoppable Sustainable Economic Growth of China. International J. of Organizational Leadership, 9, 39-47. https://doi.org/10.33844/ijol.2020.60489

24) Dhar, B.K., Hoque, M.M. and Chowdhury, R. (2014). Prospects and Problems of Green Marketing in Bangladesh. University of Science and Technology Annual, 20(6), 45-53. https://doi.org/10.6084/m9.figshare.16761898.v1

25) Dhar, B.K., Sobhani, F.A. and Absar, M.M.N. (2018). Mediating Effect of Organizational Commitment between Islamic Human Resource Practices and Organizational Performance among Islamic Banks of Bangladesh. The J. of Muamalat and Islamic Finance Research. 15(2), 54-65. https://doi.org/10.33102/jmifr.v15i2.177

26) Dhar, B.K., Mutalib, M. and Sobhani, F.A. (2017). Investigating the Impact of Human Resource Accounting Practice on Organizational Performance. In International Islamic Social Economic Conference, Universiti Sains Islam Malaysia, Malaysia.

27) Dhar, B.K., Mutalib, M. and Sobhani, F.A. (2019). Determining effective dimensions of intellectual capital. Australian Academy of Accounting and Finance Review, 4(4), 166-185. https://doi.org/10.6084/m9.figshare.16762057.v1

28) Dhar, B. K., Mutalib, M. and Sobhani, F. A. (2019). Effect of Innovation Capability on Human Capital and Organizational Performance. International Journal of Advanced Science and Technology, 29(4), 7074 - 7087.

https://doi.org/10.6084/m9.figshare.16762171.v1

29) Dhar, B. K., Mahazan, M., \& Sobhani, F. A. (2020). Overcoming Unemployment through Vocational Education: The Role of Counselors in China. Adv. in Management, 13(3), 22-25. https://doi.org/10.6084/m9.figshare.16760509.v1

30) Goetz, A. M., \& Gupta, R. S. (1996). Who takes the credit? Gender, power, and control over loan use in rural credit programs in Bangladesh. World development, 24(1), 45-63. https://doi.org/10.1016/0305-750X(95)00124-U

31) Hassan, A., Masruki, R. B., Jamil, N. N. B., \& Dhar, B. K. (2019). Shariah governance in Islamic Banks: A systematic literature review. The Business \& Management Rev., 10(5), 141-141. https://doi.org/10.6084/m9.figshare.16821451.v1

32) Hashemi, S. M., Schuler, S. R., \& Riley, A. P. (1996). Rural credit programs and women's empowerment in Bangladesh. World Development, 24(4), 635-653.

https://www.academia.edu/download/3467418/13 314_hashemi_etal.pdf

33) Hulme, D., \& Mosley, P. (1996). Finance against poverty. Routledge.

34) Idris, A. J., \& Agbim, K. C. (2015). Micro-credit as a strategy for poverty alleviation among women entrepreneurs in Nasarawa State, Nigeria. J. of Business Studies Quarterly, 6(3), 122. https://search.proquest.com/openview/919569550 24084a95507cfb510a34ec9/1?pq-origsite $=$ gschol ar\&cbl $=1056382$

35) Islam, M. N., Hossain, T., \& Afrin, S. (2014). Impact of micro-credit to reduce poverty: A case study of Mymensingh. University of Mymensingh, 31, 227-240.

https://www.researchgate.net/publication/3279441 92

36) Kabeer, N. (1999). Resources, agency, achievements: Reflections on the measurement of women's empowerment. Development and Change, 30(3), 435-464. https://doi.org/10.1111/1467-7660.00125 
37) Kabeer, N. (2001). Conflicts over credit: Reevaluating the empowerment potential of loans to women in rural Bangladesh. World Development, 29(1), 63-84.

https://doi.org/10.1016/S0305-750X(00)00081-4

38) Kabir, M. A., Dey, S., \& Islam, M. S. (2012). The role of microcredit and microfinance institutions (MFIs): Extent and intensity of poverty, poverty alleviation and outreach. International Affairs and Global Strat., 4(2), 29-47. https://www.iiste.org/Journals/index.php/IAGS/art icle/view/1457

39) Karim, M., Tania, S., \& Farazi, M. (2013). Role of micro-credit in poverty alleviation of rural poor: Evidence from Laxmipur district of Bangladesh. J. of Business and Technology, 7 (2), 37-55. https://doi.org/10.3329/jbt.v7i2.16453

40) Khan, M. A. \& Rahman, M. A. (2007). Impact of microcredit on living standards, empowerment and poverty alleviation of poor people: A case study on microcredit in the Chittagong district of Bangladesh. Umea School of Business, Master's thesis.

http://www.diva-portal.org/smash/get/diva2:14124 0/fulltext01

41) Khan, M. S. R., \& Karim, R. (2016). Impact of micro finance activities on the economic development of Bangladesh. International Journal of Finance and Banking Research, 2(1), 1-6. https:doi.org/10.11648/j.ijfbr.20160201.11

42) Khandker, S. R. (1998). Fighting poverty with microcredit: experience in Bangladesh. Oxford University Press.

43) Khandker, S. R., Khalily, M. A., \& Samad, H. A. (2015). Non-borrowing effects of microcredit participation: Evidence using long panel survey data in Bangladesh. Institute of Microcredit (InM), Dhaka. Working Paper No. 41,

44) Khanom, N. A. (2014). Rural micro credit (RMC) and poverty alleviation: the case of the PKSF in Bangladesh. International Review of Business Research Papers, 10(2), 115-136.

http://catalog.ihsn.org/citations/24545

45) Kondo, T. O. (2007). Impact of microcredit on rural households in the Philippines: A case study. Philippine Institute for Development Studies. IDS Bulletin 39(1).

46) Kondo, T. O., Aniceto Jr., \& Infantado, C. (2008). Impact of microcredit on rural households in the Philippines. Philippine Institute for Develop- ment Studies. Discussion Paper Series no. 200805. http://www.eaber.org/node/22639

47) Leach, F., \& Sitaram, S. (2002). Microfinance and women's empowerment: A lesson from India. Development in practice, 12(5), 575-588. https://doi.org/10.1080/0961452022000017597

48) Masruki, R., Khairulannuar, H. H., \& Dhar, B. K. (2020). Shariah Accountability Practice of Malaysian Foreign-Owned Islamic Banks and Bahrain Islamic Banks. International J. of $A d v$ anced Sci. and Technol., 29(4), 5768 - 5782. http://sersc.org/journals/index.php/IJAST/article/v iew/27085

49) Masruki, R., Samsudin, N. S., \& Dhar, B. K. (2020). Shariah accountability practices of Islamic banks in Malaysia. International $J$. of Advanced Science and Technology, 29(4), 6954. http://sersc.org/journals/index.php/IJAST/article/v iew/28097

50) Neponen, H. (2003). ASA-GV microcredit impact report 2003.Trihcirappalli, India.

51) Pomi, S. S. (2019). Impact of microcredit on rural poverty alleviation in the context of Bangladesh. International Journal of Economics and Finance, 11(6), 1-70.

http://www.ccsenet.org/journal/index.php/ijef/arti cle/view/0/39404

52) Pomi, S. S., Sarkar, S. M., \& Dhar, B. K. (2021). Human or physical capital, which influences sustainable economic growth most? A study on Bangladesh. Canadian Journal of Business and Information Studies, 3(5), 101-108. https://doi.org/10.34104/cjbis.021.01010108

53) Rahman, S., Junankar, P. N., \& Mallik, G. (2009). Factors influencing women's empowerrment on microcredit borrowers: a case study in Bangladesh. In Development Economics. Palgrave Macmillan, London. http://dx.doi.org/10.1080/13547860902975648

54) Raihan, S., Osmani, S. R., \& Khalily, M. A. B. (2015). Contribution of microcredit to the gross domestic product (GDP) of Bangladesh. Institute of Microcredit (InM): Dhaka. InM working Paper no 44. https://www.academia.edu/download/48303284/ Workingpaper44.pdf

55) Rathiranee, Y., \& Semasinghe, D. M. (2015). Factors determining the women empowerment through microfinance: An empirical study in Sri Lanka. International J. of Social, Behavioral, 
Educational, Economic, Business and Industrial Engineering, 9(5), 2328-2185.

http://docplayer.net/19388512-Factors-determinin g-the-women-empowerment-through-microfinanc e-an-empirical-study-in-sri-lanka.html

56) Saeed, M. A. Y., Bekhet, H. A., \& Dhar, B. K. (2018). Influence of marketing strategy audit on organizational performance through innovation capability in the corporate sector of Muscat, Oman. International J. of Business Management, 1(2), 40-55.

https://doi.org/10.6084/m9.figshare.16821457

57) Samer, S., Majid, I., Rizal, S., Muhamad, M. R., $\&$ Rashid, N. (2015). The impact of micro-finance on poverty reduction: Empirical evidence from Malaysian perspective. Procedia-Social and Behavioral Sciences, 195, 721-728.

https://doi.org/10.1016/j.sbspro.2015.06.343

58) Sarkar, S. M., Dhar, B. K. \& Rouhoma, H. M. (2018). A Cross Sectional Analysis of Socioeconomic Determinants on Infant Mortality in South Asian Region. International Journal of Business Society, 2(2), 1-6. https://doi.org/10.6084/m9.figshare.16762570.v1

59) Sarkar, S. M., Dhar, B. K., Gazi, M. A. I. (2021). Psychological Adjustment and Guidance for Ageing Urban Women, Ageing International, 1-9.

https://doi.org/10.1007/s12126-021-09467-1
60) Schechter, L. (2007). Traditional trust measureement and the risk confound: An experiment in rural Paraguay. Journal of Economic Behavior \& Organization, 62(2), 272-292. https://doi.org/10.1016/j.jebo.2005.03.006

61) Sengsourivong, K. (2006). The Impact of microcredit on household welfare: Case study of a savings group in Lao. Master Thesis. Department of Regional Cooperation Policy Studies, Kobe University, Japan.

62) Swain, R. B. (2007). The demand and supply of credit for households. Applied Economics, 39 (21), 2681-2692. https://doi.org/10.1080/00036840600749516

63) Terano, R., Mohamed, Z., \& Jusri, J. H. H. (2015). Effectiveness of microcredit program and determinants of income among small business entrepreneurs in Malaysia. J. of Global Entrepreneurship Research, 5(1), 1-14. https://doi.org/10.1186/s40497-015-0038-3

64) United Nations Development Program, (2012). International human development indicator. Country profile of human development Indicator. New York, USA.

65) United Nations Development Program, (2018). Human development indices and indicators. New York, USA.

Citation: Pomi SS. (2021). Impact of microcredit on women empowerment: a case study in the context of Chattogram district, Bangladesh. Can. J. Bus. Inf. Stud., 3(6), 120-136. https://doi.org/10.34104/cjbis.021.01200136 @ ( ) 